\title{
Relembrando Celso Aoki ${ }^{1}$
}

Friedl Paz Grünberg ${ }^{2}$

DOI: http://dx.doi.org/10.20435/tellus.vi44.776

A primeira vez que ouvi falar de Celso foi em 1979. Convidei o Rubem Almeida para uma pequena avaliação do Projeto Paĩ-Tavyterã (PPT), no Paraguai. Rubem disse ter iniciado a organização do Projeto Kaiowá Ñandeva (PKÑ) no Mato Grosso do Sul (MS), com sede em Amambai, também contou do seu primeiro colega de trabalho: Celso Aoki. Fiquei muito satisfeita porque o tempo de aprendizado do Rubem no PPT deu resultado.

No ano 1988 organizei a avaliação de 15 anos de trabalho com os Povos Guarani (PG) no Paraguai (PPT). Durante minha estadia em Pedro Juan Caballero, Celso Aoki veio por iniciativa própria me conhecer e trocar experiências de trabaIho. Esse primeiro encontro foi tão interessante que aceitei seu convite para visitá-lo na casa do projeto em Amambai onde também conheci sua esposa Myriam e seus filhos. Ele me falou que no início do PKÑ eles estavam mais preocupados com a segurança alimentar dos guarani, por isso estavam organizando as atividades do "kokue guasu - roça grande".

Conhecendo melhor a cultura guarani e os graves problemas que enfrentavam, começou a dar mais atenção à questão da terra, vendo essa questão como a causa de quase todos os grandes problemas que os indígenas enfrentavam. Falou também dos processos de reflexão entre os guarani mais velhas e velhos, sábios e guias espirituais, chegando à conclusão de que o "comportamento injusto e ruim" dos "karai - homem branco" se baseava em sua falta de valores positivos - na língua simbólica do guarani: na falta de luz. Eles decidiram fazer um esforço para trazer luz aos brancos através de grandes eventos de oração: Jeroky Guasu - Grande Oração Cantada e Dançada. Estes grandes acontecimentos tiveram o

1 Texto memorial escrito pela pesquisadora Friedl Paz Grünberg em agosto de 2020 (Viena, Áustria) sobre Celso Aoki.

2 Viena, Áustria (http://guarani.roguata.com). 
apoio do PKÑ apenas a nível logístico e foram conhecidos, apreciados e admirados por muita gente, também na Europa. A convite de Celso, Vincent Carelli realizou uma extensa vídeo-documentação sobre o Jeroky Guasu, incluindo orações que hoje já não são mais ouvidas.

No início da década de 1990, o financiamento do PKÑ tornou-se cada vez mais difícil. Em 1994, Celso participou de uma viagem de Gilberto Azanha, do Centro de Trabalho Indigenista (CTI), à Europa, como última tentativa de solução da calamidade financeira. Durante sua estadia na Áustria, ele me convidou a participar do seu empenho para entender melhor a epidemia de suicídios nas comunidades guarani.

Aí, em 1996 o Celso iniciou uma cooperação comigo (até 2004), por dois anos também com o Rubem, formando um projeto com o nome de Equipe de Acompanhamento dos Guarani (EAG), no MS Ficou claro que a epidemia ocorria quase que exclusivamente nas velhas reservas, desde 1930 forçosamente superpovoadas por comunidades adversários nesses espaços diminutos. Portanto, a questão fundiária mais uma vez foi apontada como a base do problema.

Antes do início do projeto, Celso passou por uma fase difícil de sua vida: sofreu - junto com seus colegas de trabalho - graves acusações judiciais da Fundação Nacional do Índio (FUNAI). Ele teve que fechar o PKÑ e percebeu o abuso de seus conhecimentos, que havia generosamente compartilhado com outros e que mais tarde foram aproveitados por alguns para suas carreiras científicas, sem sequer mencioná-lo.

Celso e eu iniciamos nossa cooperação trocando e refletindo sobre nossas difíceis experiências de trabalho, já em clima de confiança mútua. Este início acabou sendo uma base sólida para a nossa colaboração posterior, muito aberta e eficaz. Fiquei impressionada com o comportamento do Celso em suas visitas às comunidades, de rara sinceridade e autenticidade. As conversas foram abertas a partir de uma relação de confiança desenvolvida ao longo de muitos anos. Quase sempre a pessoa visitada iniciava o diálogo perguntando sobre um assunto que já o preocupava ou atormentava há muito tempo. Os temas eram muito vários: a questão fundiária, questões de trabalho, jurídicas, ecológicas, políticas, de saúde, de assuntos privados e memórias agradáveis ou ruins. 
Não havia limite. Celso conhecia literalmente todos os lugares onde viviam grupos guarani, conhecia o caminho para todas as Terras Indígenas (TIS), conhecia todos os líderes políticos guarani, os detalhes históricos do surgimento deles, a rede extensa de relações entre parentelas, muitas vezes desde a expulsão do seu tekoha começando nos anos 1930. A única crítica um pouco irônica de Celso foi expressada por mulheres guarani: "Que pena que Celso não fala guarani para poder conversar com mulheres". De fato, as mulheres monolíngues também poderiam ter gostado bastante de conversar com ele.

Iniciamos nosso trabalho com enfoque na questão fundiária em uma situação muito tensa no MS, já em um ambiente potencialmente violento. Encontramos os guarani quase totalmente desinformados sobre os procedimentos administrativos de regularização da terra para a restituição de seu tekoha "perdido" e sobre ações judiciais movidas pelos proprietários. Como metodologia, decidimos colaborar exclusivamente com grupos já relativamente bem organizados, que nos procuraram por iniciativa própria. Com cada grupo estabelecemos um contrato formal - verbal - com a condição de não arriscar uma "entrada" sem comunicação prévia conosco. Com essa condição tratamos de evitar assassinatos de indígenas por pistoleiros durante a ação (também chamada "retomada"), como já havia acontecido anteriormente e foi aumentando nos anos seguintes.

Em alguns casos, temos acompanhado todo o processo da identificação até a demarcação e - muito precariamente - a ocupação do tekoha. Outros casos acompanhamos apenas parcialmente, informando especialmente sobre os procedimentos formais e os dados a serem coletados. Alguns casos acompanhados demoraram mais até a primeira ocupação de seu tekoha e outros ainda estão na longa fila de espera para obter justiça.

No início de nosso trabalho, Celso ainda não estava acostumado a formular suas experiências e reflexões por escrito. Mas como teve que elaborar relatórios de trabalho, geralmente textos bastante secos, para as agências de cooperacão eles saíram em pouco tempo com mais vivacidade, às vezes comovendo fortemente as administradoras nas agências de cooperação europeias.

Para suas exposições informativas, Celso usou uma linguagem facilmente compreensivel e bem recebida pela maioria dos guarani. No entanto, percebi que os 
anciões não entendiam os procedimentos formais de testemunhar sobre a expulsão de seu tekoha tradicional, uma etapa extremamente importante durante o longo e complicado processo de regularização de seu tekoha "perdido". Muitas vezes os velhos nem entendiam seus própios líderes políticos, na sua maioria homens de meia idade e jovens, informados em cursos externos sobre "liderança" em português. Além disso, percebemos que nas comunidades as meninas e os jovens (até 18 anos) já sabiam ler guarani muito melhor do que os jovens dos anos anteriores.

Percebemos que a necessidade de conhecer e entender os procedimentos complexos para exigir o reconhecimento de um tekoha era muito grande e que era impossível para nós responder a todas essas demandas pessoalmente. Decidimos então publicar as explicações de Celso (como ele falava e não como se costuma escrever), fazendo desse texto uma tradução para o guarani moderno (jopara) e tradicional com a colaboração de dois Kaiowá. Posteriormente, quando não pude mais renovar meu contrato para viajar ao MS, Celso me contou que essas "informações básicas" tiveram uma boa e ampla recepção, tornando o karai reko melhor compreendido por todos os guarani interessados.

Celso foi uma pessoa imperturbável em seu compromisso, aprendendo da vida para a vida. Não tinha aspirações pessoais, sua única "vaidade" era poder-se comunicar bem com todos os guarani que manifestassem interesse em discutir com ele. Com o passar dos anos, ele ficou ressentido por que não era reconhecido no meio indigenista, nem por seu trabalho, nem por seus conhecimentos, em parte porque não tinha formação acadêmica. Para a alegria de todos que o conheceram e o valorizaram, isso começou a mudar com o visível apreço de Bartomeu Melià sj, do Prof. Antônio Brand e de um bom número de procuradores do Ministério Público (MP) comprometidos com a causa indígena.

Em um de seus últimos e-mails do dia 5 de março de 2020 Celso me escreveu: "[...] estou confiante que eu logo esteja podendo viajar ao MS e retomar minha vida lá. Quanto a isso não desisti ainda." Ele foi chamado para outra viagem antes que pudesse realizar seu desejo. Ele permanecerá em nossos corações, seja de ava ou karai, sem diferir em respeito e apreço por este homem corajoso e generoso - py'a guasu. 


\section{Sobre a autora:}

Friedl Paz Grünberg: Antropóloga, etnóloga e indigenista.

E-mail: friedl.gruenberg@gmx.at

Recebido em: 17/12/2020

Aprovado para publicação: 21/12/2020 
